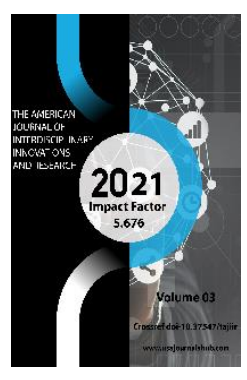

\title{
Transition To International Financial Reporting Standards In Developing Countries: Possibilities And Analysis Of Implementation
}

\author{
Samiddin Tashnazarov \\ Samarkand Institute Of Economics And Service, Uzbekistan
}

Copyright: Original content from this work may be used under the terms of the creative commons attributes 4.0 licence.

\section{ABSTRACT}

This article highlights the importance of IFRSs in developing countries, including Uzbekistan , based on the urgency of the transition to International Financial Reporting Standards (IFRSs ), and the factors that determine its necessity and potential. The most important one of the possibilities, the companies $\mathrm{x}$ International stock markets, currency exchange, capital markets and other markets in the world for the International Financial Reporting Standards, or GAAP financial reporting, and to provide in that country. The research work of the transition to IFRS to ensure the quality of the work must be done, the application of IFRS for the first time or before the transformation of the financial report based on national standards, environmental conditions, and production of composition and its contents were revealed.

\section{KEYWORDS}

International Financial Reporting Standards, Financial Reporting, Financial Report Transformation, Parallel Accounting, Financial Reporting Harmonization, Transformation Model.

\section{INTRODUCTION}

The main purpose of preparing financial statements on the basis of IFRS is to create a favorable investment climate for foreign investment in the Republic of Uzbekistan, to 
establish an effective management mechanism, to improve the quality of management decisions, to create conditions, opportunities and resources for company development. is to increase the competitiveness and cost-effectiveness of the company.

The Resolution of the President of the Republic of Uzbekistan dated February 24, 2020 DP-4611 " On additional measures for the transition to international standards of financial reporting " is aimed at addressing these issues. One of the most important issues today is the study and implementation of these IFRSs. The task is to study these international standards, their full implementation in the field of education, to develop accounting policies in enterprises and organizations in accordance with IFRS. Therefore, in developing countries, including Uzbekistan, the importance of IFRS, the opportunities and the need to set international standards for the country's socioeconomic environment, which is to ensure the quality of the transition to IFRS, IFRS moving the heading of the report and the report on the implementation of the process of transformation of it is very important to analyze, systematize the work and make decisions on the basis of accounting reform.

\section{LITERATURE REVIEW .}

J.D. Spiceland [1] issues of financial instruments and additional financial reporting,

\footnotetext{
${ }^{1}$ Tashnazarov S.N. The need to open the Institute of Professional Accounting of the Republic of Uzbekistan, its goals and objectives. // Scientific
}

D.Alixander [2] harmonization of financial statements; V.P.Astaxov [7] , V.Kachalin [6] , M.I.Kuter [5] , V.F.Paliy [4] , Ya.V.Sokolov [3] , V.I.Tkach, V Scholars such as G. Hetman [ 8 ], T. Yu. Drujilovskaya [9] have studied the application of IFRS in their work.

Many scientists from country to country in their work a give those who study the issues of transition to IFRS. I. Ochilov [10] studied the issues of preparation and submission of financial statements in insurance companies. In his article, Marpatov [11] addressed the issue of harmonization of the financial statements with international standards .

Our research $[12,13]$ substantiates the need, essence and stages of transformation of financial reporting in accordance with IFRS and the need to open the Institute of Professional Accounting of the Republic of Uzbekistan, its goals and objectives .' But today, at the international level in developing countries, a multiples, including the specifics of the transition to IFRS, it is performed step-by-step implementation of a systematic review of the research is relatively low. Therefore, research on this topic is a topical issue.

\section{ANALYSIS AND RESULTS}

There will be radical changes in the content, function and participation of this industry in management. IFRSs are widely introduced all over the world, including in my country. All over the world within the next 20-30 years the level of financial reporting harmonization

electronic journal "International Finance and Accounting". - Tashkent, 2018. - №4-5. B.1-13. (08.00.00; №19) 
achieved. In order to move quickly to this process, we need to accelerate the application of IFRS in our country through professional institutes of accountants, organize training of our specialists in IFRS abroad, introduce special programs on IFRS. This is an urgent issue .

IFRS is a system of setting general rules and principles of preparation and presentation of information for information users located in different countries on the basis of world achievements of accounting. While compliance with IFRS $s$ is not legally binding, they are of a recommendatory nature. ${ }^{2}$

The importance of IFRSs, their necessity and capabilities are determined by the following factors :

- Countries will have the opportunity to introduce a world-recognized methodology that is tested in the preparation and submission of financial statements, gives a well-thought-out and expected effect, and most importantly provides quality, objective and timely information;

- National standards, the development of rules and international standards and norms will have a chance to use (Russia, Kazakhstan and Uzbekistan is also very important for the role );

- International stock markets, currency exchange, capital markets and other markets in the world for the International

\footnotetext{
${ }^{2}$ Ortikniyozovich, FU (2020). Theme: Forecasts And Results Of The Negative Impact Of The Covid-19 (Coronavirus) Pandemic On The World Economy
}

Financial Reporting Standards, or GAAP financial reporting, and to be in demand;

- Require reporting on the basis of IFRS when receiving foreign currency from the European Bank for Reconstruction and Development, the World Bank, the Asian Development Bank, the International Monetary Fund;

- In order to attract foreign investment to the country for foreign investors and financial reporting in accordance with IFRS or GAAP requires the structure of the work - Attracting foreign investment and cooperation with foreign investors will increase ;

- Export and import operations by foreign partners in the implementation of financial reporting based on IFRS ;

- The presence of high inflation in the economy of this process, taking into account financial report for as long as necessary to occur;

- The government has decided to joint-stock companies, enterprises with foreign investment or the introduction of financial statements in accordance with IFRS requires the transformation of the work ;

- Applies companies and organizations with their own initiative decided to go to work;

- Increases the transparency of the company's performance;

And The Economy Of Uzbekistan. The American Journal of Interdisciplinary Innovations and Research, 2 (08), 108-116. 
- Users of information have the opportunity to analyze the financial performance of a single company by period, and by comparing the performance of several different companies;

- Lenders, shareholders, lending institutions increase confidence in the company and invest in the company's activities with high confidence, the company's access to credit expands;

- Managers of the company will have the opportunity to obtain reliable, objective, relevant and timely systematized financial information to make management decisions;

- Provides necessary information in the budgeting, planning and strategic development assessment of the company;

- Improving the company's management mechanisms, increasing the company's competitiveness, improving product quality;

- Eliminate elements of corruption, abuse, concealment of tax objects, looting, localization, homelessness, bankruptcy in companies;

- The system of labor incentives will be radically improved, material interest will increase.

- A powerful control system is installed. The spiritual environment is stabilized. Employees' loyalty to their work, company and country are combined.
- Employees have the opportunity to work on themselves and constantly improve their skills.

In order to ensure the quality of the transition to IFRS, in our opinion, we need to do the following:

First, we need to translate IFRS into Uzbek, create terms on IFRS. An initial interpretation of the terms was developed to discuss them. Suggestions on the terms created were sent to leading accounting organizations. Important work in this regard is the International Financial Reporting Standards in the Uzbek language will need to be recognized by the Council on International Standards.

Second, the introduction of IFRSs requires reform in the field of accounting and auditing in higher education. The field that creates the theoretical and methodological basis of science is higher education. Because higher education creates modern textbooks on accounting and auditing, conducts research in the field.

It is not possible to go directly to the IFRS at any time, without preparation. Even if unprepared financial statements are transformed under IFRSs, they will not produce the expected results. Therefore, the environment, conditions and certain preparatory work must be carried out before applying IFRSs for the first time or before transforming a financial statement prepared on the basis of national standards. We consider it appropriate to include the following in these factors:

- The country's financial, monetary, tax, labor legislation must meet world 
standards. It is necessary to achieve free conversion of the national currency;

- There should be no high inflation rate in the country's economy;

- We must ensure that the system of national accounting standards of the Republic of Uzbekistan is as consistent as possible with IFRS. If the difference in the middle is large, the transformation process is complicated, and even if transformed, it does not give the expected result;

- The normative legal document in the conduct of accounting and preparation and submission of financial statements should be only the Law on Accounting and accounting standards. We also need to gradually turn regulations, guidelines and rules into standards;

- We need to create a single system of standards in economic entities, banking systems and public funds (regardless of whether they aim to make a profit) or not, so that the rules apply to all types of companies and organizations in the same way. need;

- It should be possible to move to a procedure for freely determining the currency of financial reporting in accordance with international standards;

- It is necessary to establish an institute of professional accountants in the country, to improve the professional skills of certified accountants and auditors within its competence, to expand the widespread introduction of SAR and CIPA certificates ;

- It is necessary to improve the skills of accountants abroad, to learn foreign languages (IELTS), to develop the skills of practicing accountants to work in international accounting programs;
- Companies need to bring their corporate governance systems in line with international standards;

- Improving the system of financial incentives for accountants, ensuring their compliance with the rules of ethics;

- Improving the accounting policy of companies, its structure in full compliance with the principles of financial reporting and the existence of a true accounting project, as well as the development of a chart of accounts in the company in accordance with international standards;

- We believe that the company needs to ensure that accounting and financial reporting are conducted on the basis of special programs and carry out a number of other activities.

Analyzing the above systems, in our opinion, it is advisable to keep a parallel account if the financial capabilities of the company match. Because this account provides the most important objective information, the risk of error is low. In addition, if the system requires more costs in the early years when it is installed, the costs will be optimized after the system is fully operational, i.e., costs will be lower in subsequent years.

\section{CONCLUSIONS AND RECOMMENDATIONS}

Based on the above research, the following conclusions were reached:

1. One of the most important issues for countries that are currently transitioning to IFRSs, including Uzbekistan, is the study and implementation of IFRSs. The introduction of IFRS in our country requires a gradual implementation. For this 
purpose, it is important to translate IFRS into Uzbek, to cooperate with international professional organizations, to certify accountants, to bring the content of academic disciplines in universities in line with international practices, to address issues of international accreditation.

2. The research reveals the importance of IFRS, its necessity and opportunities. Today, the transition to IFRS for Uzbekistan opens up great opportunities, such as access to world markets, improving the investment climate, attracting foreign investment and credit, expanding the volume of export and import operations.

3. The transition to International Financial Reporting Standards requires certain conditions in the country. These conditions include the establishment of a world-class management system in business units, the formation of a financial and banking system in the country in accordance with international requirements and market infrastructure, the existence of independent, non-governmental public accounting professional organizations, a system of business laws, certified, professional accountants, factors such as the adoption of international terminology in accounting were included.

4. In order to ensure the quality of the transition to IFRSs, it is necessary to achieve the recognition of international standards in the Uzbek language by the Council for International Financial Reporting Standards. The introduction of IFRSs requires reforming the accounting and auditing system in higher education. The naming and content of sciences should be fully aligned with international practices.
In conclusion, the transition to IFRS in developing countries is largely determined by the organization of work, the definition of the work to be done, the definition of the environment and conditions, the sequence and stages of the work to be done in the transformation process. The suggestions and recommendations presented in this article will serve to ensure a gradual quality transition to IFRSs.

\section{REFERENCES}

1. Spiceland J. David. Intermediate accounting. /J.David Spiceland, James F. Sepe. Mark W. Nelson / 7 th ed. 2013 ; International Financial Reporting and Analysis, 4th Edition. D . Alexander, A . Britton , A . Jorissen . 2009. 39-59 - p

2. Ya.V.Sokolov. Essays on the history of accounting. - $\mathrm{M}$.: Finance and statistics, 1991. - 400 p. ;

3. V.F.Paliy . International Financial Reporting Standards. - M .: INFRA- M., 2003-456p. ;

4. M.I.Kuter - Theory and principles of accounting: Ucheb. posobie.-M .: financier Statistical Bureau Ekspertnoe, 2000.-544 S ;

5. V.V.Kachalin. Finansovyy uchet $\mathrm{i}$ otchetnost v sootvetstvie so standartami GAAP. - M .: Delo, 1998. -432 s. ;

6. V.P.Astaxov . Theory of accounting .»Publishing center« MarT », 2000. - 416 p. ;

7. Ortikniyozovich, FU (2020). Theme: Forecasts And Results of The Negative Impact Of The Covid-19 (Coronavirus) Pandemic On The World Economy And The Economy Of Uzbekistan. The American Journal of Interdisciplinary Innovations and Research, 2 (08), 108-116.

8. C.G. Getman. On kontseptualnoy osnove mejdunarodnyx standartov finansovoy 
otchetnosti // Mejdunarodnyy buhgalterskiy uchet, 2007, № 12 ;

9. T.Yu.D ruzhilovskaya $G$ harmonization of financial reporting: theory and Russian practice. Abstract of doctoral dissertation on economics Scientific library of dissertations and abstracts of dissertationsCat

http://www.dissercat.com/content/kontsep tsiya-i-metodika-formirovaniya-finansovoiotchetnosti-v-uchete\#ixzz58bGv

10. I.Ochilov. Preparation and submission of financial statements in insurance companies. // Market, money and credit J. 2012.-№7.-B. 57-61.

11. M.Marpatov. Balance sheet is a statement of financial position. // Market, money and credit J. -2016.-№11.-B. 20-24.

12. Sevara Babanazarova (2020) "About ensuring a fair approach to the effective organization of the professors and teachers work.", Middle European Scientific Bulletin, 5, pp. 88-91. doi: 10.47494 / mesb.2020.5.65.

13. Tashnazarov S.N. M Applies oliyaviy report on the need for transformation, the nature and stages // Economy and the innovative technology of electronic scientific journal . Tashkent, 2017 . - № 3 . B. 1-16.

14. Tashnazarov S.N. The need to open the Institute of Professional Accounting of the Republic of Uzbekistan, its goals and objectives. // Scientific electronic journal "International Finance and Accounting". Tashkent, 2018. - №4-5. B.1-13. 